\title{
Reclassification of Amycolatopsis rugosa Lechevalier et al. 1986 as Prauserella rugosa gen. nov., comb. nov.
}

\author{
Seung Bum Kim and Michael Goodfellow
}

Department of

Agricultural and

Environmental Science, University of Newcastle, Newcastle upon Tyne NE1 7RU, UK

\author{
Author for correspondence: Seung B. Kim. Tel: +44 191222 5922. Fax: +44 1912225228. \\ e-mail: s.b.kim@ncl.ac.uk
}

Keywords: Prauserella rugosa, 16S rDNA sequencing, polyphasic taxonomy

\section{INTRODUCTION}

Nocardia rugosa was proposed by Di Marco \& Spalla (1957) to accommodate actinomycetes isolated from cattle rumen. The taxon was well described but a type strain was not designated until the species was transferred to the genus Amycolatopsis as Amycolatopsis rugosa (Lechevalier et al., 1986). The type strain forms a substrate mycelium which has the following characteristics: it undergoes fragmentation (Di Marco \& Spalla, 1957; Lechevalier et al., 1986); it contains meso-diaminopimelic acid, arabinose and galactose (Lechevalier et al., 1986; Whitehead, 1989), that is, it has a wall chemotype IV sensu Lechevalier \& Lechevalier (1970); it contains complex mixtures of branched-chain and saturated fatty acids (Henssen et al., 1987; Mertz \& Yao, 1993); it lacks mycolic acids (Lechevalier et al., 1986; Henssen et al., 1987) and contains muramic acid in the $N$-acetylated form (Henssen et al., 1987); it has di- and tetrahydrogenated menaquinones with nine isoprene units as the predominant isoprenologue (Lechevalier et al., 1986; Yassin et al., 1991) and has major amounts of diphosphatidylglycerol, phosphatidylglycerol, phos-

The GenBank accession number for the 16S rDNA sequence of strain DSM $431194^{\top}$ is AF051342. phatidylinositol, phosphatidylethanolamine and phosphatidylmethylethanolamine, with the latter two components acetylated to hydroxy fatty acids (Lechevalier et al., 1986; Yassin et al., 1993). The $\mathrm{G}+\mathrm{C}$ content of the DNA of the type strain has been reported to be 67.0 (Akimov et al., 1989) and 68.9 mol \% (Lechevalier et al., 1986).

It seems likely that $A$. rugosa is misclassified in the genus Amycolatopsis. Representatives of the taxon have been repeatedly assigned to a homogeneous cluster, sharply separated from clusters corresponding to validly described species of the genera Amycolatopsis, Kibdelosporangium, Pseudonocardia, Saccharomonospora and Saccharopolyspora, in extensive numerical phenetic surveys of wall-chemotype IV actinomycetes lacking mycolic acids (Mattinson-Rose, 1986; Whitehead, 1989). The type strain of A. rugosa was also separated from representatives of most other Amycolatopsis species in studies of DNA-DNA relatedness (Labeda, 1995), cellular fatty acids (Mertz \& Yao, 1993) and phage host-range (Lechevalier et al., 1986) and in non-numerically based phenotypic studies (De Boer et al., 1990).

Sequencing of $16 \mathrm{~S}$ rDNA provides a powerful way of distinguishing between actinomycetes that have proved difficult to classify by standard phenotypic methods (Chun \& Goodfellow, 1995; Chun et al., 
1997; Kim et al., 1998). The present study was designed to determine whether 16S rDNA sequencing could be used to help resolve the taxonomic status of $A$. rugosa.

\section{METHODS}

Organisms and culture conditions. The type strain of $A$. rugosa was received from the Deutsche Sammlung von Mikroorganismen und Zellkulturen (DSMZ; Braunschweig, Germany) and from the National Collection of Industrial and Marine Bacteria (NCIMB; Aberdeen, UK). Cultures of strains DSM $43194^{\mathrm{T}}$ and NCIMB $8926^{\mathrm{T}}$ were maintained on modified Bennett's agar plates (Jones, 1949) and as suspensions in $20 \%(\mathrm{v} / \mathrm{v})$ glycerol at $-20^{\circ} \mathrm{C}$.

Morphology. The colonial and pigmentational properties of the test strains were examined on plates of inorganic saltsstarch agar (ISP medium 4; Difco) (Shirling \& Gottlieb, 1966), nutrient agar (Difco) and Czapek Dox-yeast extract agar (Cross \& Attwell, 1974) after $14 \mathrm{~d}$ at $28^{\circ} \mathrm{C}$.

16S rDNA sequencing. Extraction of chromosomal DNA, PCR amplification and direct sequencing of the amplified products from the test strains were performed according to the procedure described by Kim et al. (1996). A primer designated 342r (5' GGAGTCTGGGCCGTGTCTC 3') was used for direct sequencing in addition to the previously described primers (Chun \& Goodfellow, 1995).

Phylogenetic analysis. The $16 \mathrm{~S}$ rDNA sequences were aligned manually with the AL16S program (Chun, 1995) against corresponding nucleotide sequences of representatives of the family Pseudonocardiaceae (Stackebrandt et al., 1997) retrieved from the EMBL and GenBank databases. Phylogenetic trees were inferred by using the Fitch-Margoliash (Fitch \& Margoliash, 1967), neighbourjoining (Saitou \& Nei, 1987) and maximum-parsimony (Kluge \& Farris, 1969) treeing algorithms from the PHYLIP package (Felsenstein, 1993). Evolutionary distance matrices for the Fitch-Margoliash and neighbour-joining methods were generated as described by Jukes \& Cantor (1969). Tree topologies were evaluated by bootstrap analysis based on 1000 resamplings of the neighbour-joining dataset by using the SEQBOOT and CONSENSE options from the PHYLIP suite of programs (Felsenstein, 1993). The root position of the tree based on the neighbour-joining method was estimated by using four outgroup organisms, Arthrobacter globiformis (GenBank accession no. M23411), Bacillus subtilis (K00637), Escherichia coli (J01695) and Streptomyces ambofaciens (M27245), as described by Swofford \& Olsen (1990).

\section{RESULTS AND DISCUSSION}

The almost complete 16S rDNA sequences (1519 nucleotides) obtained for $A$. rugosa strains DSM $43194^{\mathrm{T}}$ and NCIMB $8926^{\mathrm{T}}$ were identical. Comparison of this common sequence with those of corresponding sequences of representatives of the family Pseudonocardiaceae (Warwick et al., 1994; Stackebrandt et al., 1997) showed the organism to be loosely associated with the genus Saccharomonospora in the phylogenetic trees based on the neighbour-joining and FitchMargoliash algorithms (Fig. 1). In the corresponding maximum-likelihood tree, the strain formed a distinct clade within the evolutionary radiation encompassed by the family Pseudonocardiaceae. The test strain also showed a pattern of 16S rDNA sequences characteristic of this family (Stackebrandt et al., 1997). The family Pseudonocardiaceae recognized by Stackebrandt et al. (1997) included the genera Actinosynnema, Saccharothrix and Streptoalloteichus; these taxa were omitted from the family by Warwick et al. (1994), who considered that they might form a sister group to the family Pseudonocardiaceae. This now seems to be the case, as Labeda (1998) has suggested that the genera Actinokineospora, Actinosynnema, Lentzea and Saccharothrix should be assigned to a putative new taxon, the family 'Actinosynnemaceae'. The 16S rDNA data suggest that the genera Kutzneria and Streptoalloteichus might also belong to this group (Fig. 1). These propositions leave the family Pseudonocardiaceae as a relatively homogeneous group (Embley et al., 1988; Warwick et al., 1994).

The chemical and morphological properties of $A$. rugosa DSM $43194^{\mathrm{T}}$ show that it is correctly classified in the family Pseudonocardiaceae sensu stricto. Thus, the organism forms a substrate mycelium that fragments into irregularly shaped elements (Di Marco \& Spalla, 1957; Lechevalier et al., 1986), produces an acetylated peptidoglycan (Henssen et al., 1987), has wall chemotype IV (Lechevalier et al., 1986; Whitehead, 1989), is rich in branched-chain and saturated fatty acids (Henssen et al., 1987; Mertz \& Yao, 1993), contains di- and tetrahydrogenated menaquinones with nine isoprene units as the predominant isoprenologue (Lechevalier et al., 1986; Yassin et al., 1991), contains diphosphatidylglycerol and phosphatidylethanolamine as diagnostic polar lipids (Lechevalier et al., 1986; Yassin et al., 1993) and has DNA with a high $\mathrm{G}+\mathrm{C}$ content (Lechevalier et al., 1986; Akimov et al., 1989) but which lacks mycolic acids (Lechevalier et al., 1986; Henssen et al., 1987).

Two main types of phospholipid patterns have been detected in members of the family Pseudonocardiaceae (Embley et al., 1988; Lechevalier et al., 1977, 1986; Shearer et al., 1986). Representatives of the genera Pseudonocardia and Saccharopolyspora contain phosphatidylcholine and phosphatidylethanolamine derivatives as their major phospholipids (phospholipid type III sensu Lechevalier et al., 1977). A. rugosa, together with members of the genera Amycolatopsis, Kibdelosporangium and Saccharomonospora, lack phosphatidylcholine and contain phosphatidylethanolamine and derivatives as major phospholipids (phospholipid type II).

The highest mean 16S rDNA identities found between the type strain of $A$. rugosa and other members of the family Pseudonocardiaceae sensu stricto were with representatives of the genera Amycolatopsis (93.8\%), Pseudonocardia (92.5\%), Saccharomonospora (94.7\%) and Thermocrispum (93.2\%). Mean identities within or just outside this range are found between established genera classified within this family: for instance, between the genera Amycolatopsis and Saccharopolyspora $(93.4 \%)$ and between Pseudonocardia and Saccharomonospora $(92 \cdot 1 \%)$. A. rugosa can also be 


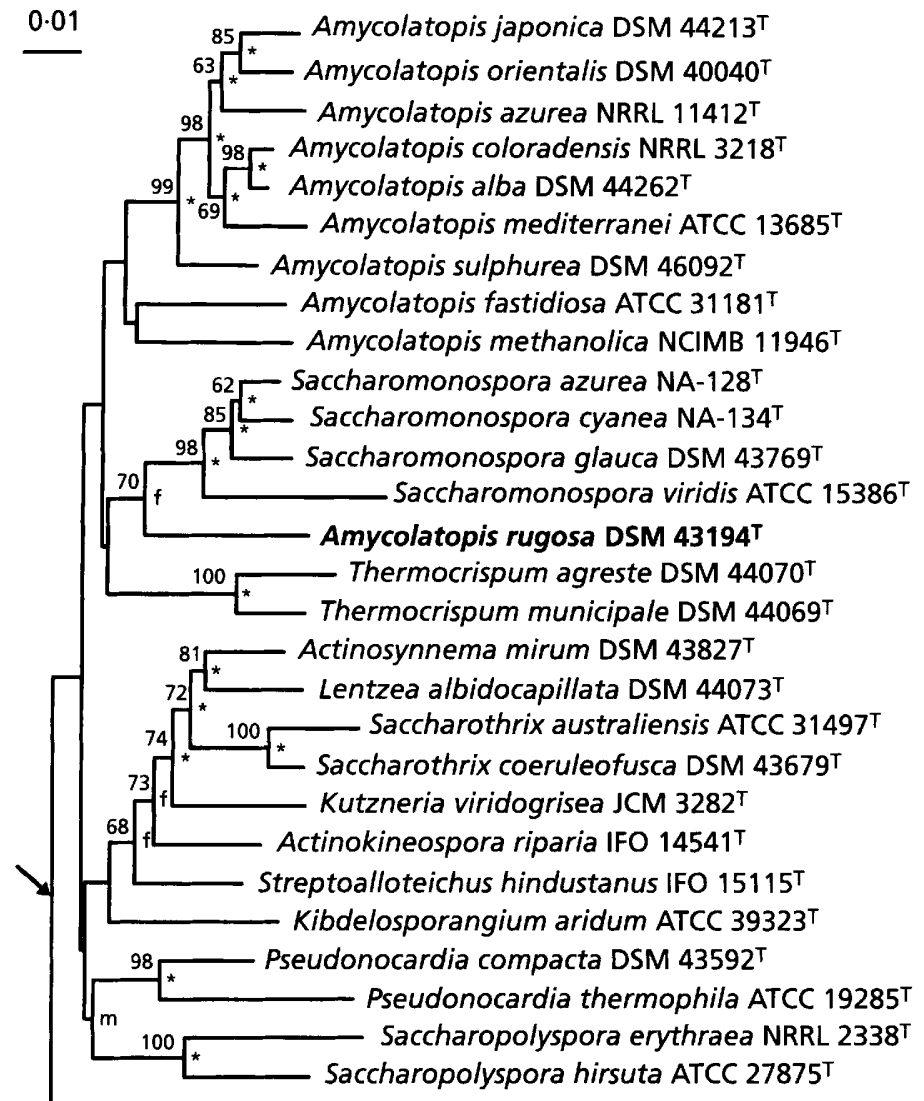

Actinopolyspora halophila ATCC 27976
Fig. 1. Neighbour-joining tree (Saitou \& Nei, 1987), based on 16S rDNA sequences, showing relationships between $A$. rugosa strain DSM $43194^{\top}$ and representatives of the family Pseudonocardiaceae and related taxa. Asterisks indicate branches recovered with all three methods; $f$ and $m$ indicate branches that were also recovered by using the Fitch-Margoliash (Fitch \& Margoliash, 1967) and maximum-parsimony (Kluge \& Farris, 1969) treeing algorithms, respectively. The numbers at the nodes indicate the levels of bootstrap support based on a neighbourjoining analysis of 1000 resampled datasets; only values above $50 \%$ are given. The arrow indicates the estimated position of the four root organisms. The scale bar indicates 0.01 nucleotide substitutions per nucleotide position.

Table 1. Diagnostic characters that separate $A$. rugosa from representatives of genera classified in the family Pseudonocardiaceae sensu stricto

Data were taken from earlier studies: Lechevalier et al. (1986); Shearer et al. (1986); Labeda (1987); Henssen et al. (1987); Akimov et al. (1989); Goodfellow et al. (1989); Korn-Wendisch et al. (1989, 1995); Yoshida et al. (1991); Reichert et al. (1998). + , Present or positive; -, absent or negative; $\mathrm{v}$, variable; ND, not determined.

\begin{tabular}{|c|c|c|c|c|c|c|c|c|}
\hline Character & A. rugosa & Actinopolyspora & Amycolatopsis & Kibdelosporangium & Pseudonocardia & Saccharomonospora & Saccharopolyspora & Thermocrispum \\
\hline \multicolumn{9}{|l|}{ Morphological features: } \\
\hline Acropetal budding & - & - & - & - & + & - & - & - \\
\hline Aerial hyphae & - & + & + & + & + & + & + & + \\
\hline Spores on aerial hyphae & - & In chains & In chains & In chains & In chains & Singly & In chains & In chains \\
\hline Fragmentaion of substrate hyphae & + & $\mathrm{v}$ & + & + & $\mathrm{v}$ & - & + & - \\
\hline Spores on substrate hyphae & - & - & + & - & + & - & $\mathrm{v}$ & $\mathrm{ND}$ \\
\hline Sporangia-like structures & - & - & - & + & - & - & - & + \\
\hline \multicolumn{9}{|l|}{$\begin{array}{l}\text { Chemical properties: } \\
\text { Cons }\end{array}$} \\
\hline Phospholipid type* & 2 & 3 & 2 & 2 & 2,3 & 2 & 3 & 2 \\
\hline Diagnostic whole-cell sugars & $\begin{array}{c}\text { Arabinose, } \\
\text { galactose }\end{array}$ & $\begin{array}{c}\text { Arabinose, } \\
\text { galactose }\end{array}$ & $\begin{array}{c}\text { Arabinose, } \\
\text { galactose }\end{array}$ & $\begin{array}{c}\text { Arabinose, } \\
\text { galactose }\end{array}$ & $\begin{array}{c}\text { Arabinose, } \\
\text { galactose }\end{array}$ & $\begin{array}{c}\text { Arabinose, } \\
\text { galactose }\end{array}$ & $\begin{array}{c}\text { Arabinose, } \\
\text { galactose }\end{array}$ & None \\
\hline Predominant menaquinone(s) $\dagger$ & $9\left(\mathrm{H}_{2}, \mathrm{H}_{4}\right)$ & $9\left(\mathrm{H}_{4}, \mathrm{H}_{6}\right), 10\left(\mathrm{H}_{4}\right)$ & $9\left(\mathbf{H}_{2}, \mathbf{H}_{4}, \mathbf{H}_{6}\right)$ & $9\left(\mathrm{H}_{4}\right)$ & $8\left(\mathbf{H}_{2}, \mathbf{H}_{4}\right)$ & $8\left(\mathrm{H}_{4}\right), 9\left(\mathrm{H}_{4}\right)$ & $9\left(\mathrm{H}_{4}\right), 10\left(\mathrm{H}_{4}\right)$ & $9\left(\mathrm{H}_{4}\right)$ \\
\hline DNA G + C content (mol \%) & $67 \cdot 0-68 \cdot 9$ & $64-68$ & $66-73$ & $66^{4}$ & $69-74$ & $66-70$ & $70-77$ & $69-73$ \\
\hline Extreme halophile & - & + & - & - & - & - & - & - \\
\hline
\end{tabular}

*Abbreviated as 2, phosphatidylethanolamine and 3, phosphatidylcholine (with phosphatidylethanolamine, phosphatidylmethylethanolamine and phosphatidylglycerol variable; no phospholipids containing glucosamine) (Lechevalier et al., 1977).

$\dagger$ Abbreviations are exemplified by $9\left(\mathrm{H}_{4}\right)$, menaquinones having two of the nine isoprene units hydrogenated.

distinguished from other members of the family Pseudonocardiaceae sensu Warwick et al. (1994) by using a combination of biochemical, chemical, morphological and physiological markers (Table 1). The failure of $A$. rugosa strains DSM $43194^{\mathrm{T}}$ and NCIMB $8926^{\mathrm{T}}$ to form aerial hyphae on Czapek Dox-yeast extract, inorganic salts-starch and nutrient agars is consistent with observations from previous studies (Di 
The genotypic and phenotypic data show that $A$. rugosa DSM 43194 ${ }^{\mathrm{T}}$ (=NCIMB $8926^{\mathrm{T}}$ ) does not belong to the genus Amycolatopsis but should be classified in a new genus within the family Pseudonocardiaceae Warwick et al. (1994). It is therefore proposed that Amycolatopsis rugosa be classified in the genus Prauserella gen. nov. as Prauserella rugosa gen. nov., comb. nov.

\section{Description of Prauserella gen. nov.}

Prauserella (Prau.se.rel'la. M.L. dim. ending -ella; M. L. fem. n. Prauserella named after Helmut Prauser, a German microbiologist who made many contributions to actinomycete systematics). The description is based on data taken from this and earlier studies (Di Marco \& Spalla, 1957; Lechevalier et al., 1986; Henssen et al., 1987).

Aerobic, Gram-positive, non-acid-alcohol-fast, nonmotile actinomycetes that form an extensively branched substrate mycelium $(0.6-0.8 \mu \mathrm{m}$ in diameter $)$ which fragments into irregular rods within $24-48 \mathrm{~h}$ on rich media. Aerial hyphae are not formed. Produce cream to yellowish, glistening colonies that may be wrinkled or folded. Good growth occurs on asparagine, modified Bennett's, Czapek Dox-yeast extract, glycerine and nutrient agars. Brownish, soluble pigments are formed on some media. The temperature range for growth is $10-45^{\circ} \mathrm{C}$ with the optimum temperature of $34^{\circ} \mathrm{C}$. Grow optimally between $\mathrm{pH} 6.8$ and 7.2. Contain meso-diaminopimelic acid as the diamino acid, an acetylated peptidoglycan, major amounts of arabinose and galactose, di- and tetrahydrogenated menaquinones with nine isoprene units as the predominant isoprenologue and diphosphatidylglycerol and phosphatidylethanolamine as diagnostic polar lipids, have a fatty-acid profile rich in branchedchain and saturated components and lack mycolic acids. The genus belongs to the family Pseudonocardiaceae Warwick et al. (1994). The type and only species is Prauserella rugosa.

\section{Description of Prauserella rugosa gen. nov., comb. nov.}

Prauserella rugosa (ru.go'sa. L. adj. rugosa wrinkled). The description is based on results from this and earlier studies (Di Marco \& Spalla, 1957; Lechevalier et al., 1986; Akimov et al., 1989; Whitehead, 1989; Mertz \& Yao, 1993).

Cream coloured, irregular, flat and veined colonies $(10 \times 6 \mathrm{~mm})$ formed on Czapek Dox-yeast extract agar. Arbutin, casein, hypoxanthine, L-tyrosine, tributyrin and Tweens 20,40,60 and 80 are degraded but adenine, elastin, starch and testosterone are not. Aesculin, allantoin and urea are hydrolysed and phosphatase is produced but nitrate is not reduced. Hydrogen sulphide is not formed but the organism is sensitive to lysozyme. Acetate, benzoate, lactate, malate, propionate, pyruvate and succinate are decarboxylated but citrate, mucate, oxalate and tartrate are not. Acid is formed from adonitol, arabinose, erythritol, fructose, galactose, glucose, glycerol, mannitol, mannose, rhamnose, salicin, trehalose and xylose but not from cellobiose, dextrin, inositol, lactose, maltose, melibiose, methyl $\alpha$-D-glucoside, raffinose, sorbitol, sucrose or methyl $\beta$-D-xyloside. Utilizes adonitol, amygdalin, (+)-L-arabinose, arbutin, cellobiose, dextrin, erythritol, fructose, galactose, glucose, glycerol, glycogen, lactose, maltose, mannitol, mannose, rhamnose, ribose, salicin, sucrose, trehalose, xylitol and xylose as sole sources of carbon for energy and growth but not arabitol, dulcitol, (+)-D- or ( - )-Lfucose, gentibiose, inositol, sorbitol or turanose (all sugars at $1 \%, w / v)$. Similarly, L-alanine, androsterone, cholesterol, ergosterol, L-glycine, L-proline, protocatechuic acid, shikimic acid, butyrate, propionate, pyruvate, succinate and L-tyrosine are used as sole carbon sources but not $\mathrm{D}-\alpha$-alanine, $\mathrm{L}$-arginine, $\mathrm{L}$ asparagine, catechol, L-citrulline, creatine, L-cysteine, L-citrulline, ferulic acid, histamine, L-hydroxyproline, phthallic acid, progesterone, quinic acid, L-serine, fumarate, tartrate, syringealdehyde, L-threonine or vanillin (all at $0.1 \%, \mathrm{w} / \mathrm{v}$ ). Growth occurs in the presence of cephaloridine hydrochloride $\left(2 \mu \mathrm{g} \mathrm{ml}^{-1}\right)$, demeclocycline hydrochloride $\left(2 \mu \mathrm{g} \mathrm{ml}^{-1}\right)$, lincomycin hydrochloride $\left(10 \mu \mathrm{g} \mathrm{ml}^{-1}\right)$, neomycin sulphate $(3 \mu \mathrm{g}$ $\left.\mathrm{ml}^{-1}\right)$, oleandomycin phosphate $\left(2 \mu \mathrm{g} \mathrm{ml}^{-1}\right)$, penicillin $\mathrm{G}\left(10 \mu \mathrm{g} \mathrm{m}^{-1}\right)$, streptomycin sulphate $\left(16 \mu \mathrm{g} \mathrm{ml}^{-1}\right)$ and vancomycin hydrochloride $\left(0.25 \mu \mathrm{g} \mathrm{ml}^{-1}\right)$ but not in the presence of cephaloridine hydrochloride $(25 \mu \mathrm{g}$ $\left.\mathrm{ml}^{-1}\right)$, chloramphenicol $\left(25 \mu \mathrm{g} \mathrm{ml}^{-1}\right)$, gentamicin sulphate $\left(0.5 \mu \mathrm{g} \mathrm{ml}^{-1}\right)$, kanamycin sulphate $\left(5 \mu \mathrm{g} \mathrm{ml}^{-1}\right)$, rifampicin $\left(2 \mu \mathrm{g} \mathrm{ml} \mathrm{m}^{-1}\right)$, tetracycline hydrochloride $\left(5 \mu \mathrm{g} \mathrm{ml}^{-1}\right)$ or tobramycin sulphate $\left(8 \mu \mathrm{g} \mathrm{ml}^{-1}\right)$. Similarly, growth occurs in the presence of bismuth citrate $\left(1 \mu \mathrm{g} \mathrm{ml}^{-1}\right)$, crystal violet $\left(1 \mu \mathrm{g} \mathrm{ml}^{-1}\right)$, phenol $(100 \mu \mathrm{g}$ $\left.\mathrm{ml}^{-1}\right)$, phenyl ethanol $(0 \cdot 1 \%, \mathrm{v} / \mathrm{v})$, potassium tellurite $\left(10 \mu \mathrm{g} \mathrm{ml}^{-1}\right)$, sodium azide $\left(1 \mu \mathrm{g} \mathrm{ml}^{-1}\right)$, teepol $(100 \mu \mathrm{g}$ $\left.\mathrm{ml}^{-1}\right)$, tetrazolium $\left(100 \mu \mathrm{g} \mathrm{ml} \mathrm{m}^{-1}\right)$, thallous acetate $\left(10 \mu \mathrm{g} \mathrm{ml}^{-1}\right)$ and sodium chloride $(13 \%, \mathrm{w} / \mathrm{v})$ but not in the presence of adenine $(0.4 \% \mathrm{w} / \mathrm{v})$, crystal violet $\left(10 \mu \mathrm{g} \mathrm{ml}^{-1}\right)$, phenyl ethanol $(0.4 \%, \mathrm{v} / \mathrm{v})$, potassium tellurite $\left(100 \mu \mathrm{g} \mathrm{ml}^{-1}\right)$, sodium azide $\left(100 \mu \mathrm{g} \mathrm{ml}^{-1}\right)$ or thallous acetate $\left(100 \mu \mathrm{g} \mathrm{m}^{-1}\right)$. The DNA G $+\mathrm{C}$ content of the type strain has been reported to be 67.0/68.9 mol $\%$ by the $T_{m}$ method. The type strain produces vitamin $\mathrm{B}_{12}$. Isolated from cattle rumen. The type strain of Prauserella rugosa is DSM $43194^{\mathrm{T}}$ (= ATCC $43014^{\mathrm{T}}=$ NCIMB $8926^{\mathrm{T}}$ ).

\section{ACKNOWLEDGEMENTS}

Part of this work was supported by a BBSRC grant (R185/05688/01). S.B.K. is grateful for support from a Chevening-MOST scholarship. The authors are indebted to R. M. Kroppenstedt for providing the type strain of Amycolatopsis rugosa and to K. P. Schaal for help with the nomenclature. 
Akimov, V. N., Evtushenko, L. I. \& Dobritsa, S. V. (1989). Pseudoamycolata halophobica gen. nov., sp. nov. Int J Syst Bacteriol 39, 457-461.

Chun, J. (1995). Computer-assisted classification and identification of actinomycetes. $\mathrm{PhD}$ thesis, University of Newcastle upon Tyne.

Chun, J. \& Goodfellow, M. (1995). A phylogenetic analysis of the genus Nocardia with 16S rRNA gene sequences. Int $J$ Syst Bacteriol 45, 240-245.

Chun, J., Blackall, L. L., Kang, S.-O., Hah, Y. C. \& Goodfellow, M. (1997). A proposal to reclassify Nocardia pinensis Blackall et al. as Skermania piniformis gen. nov., comb. nov. Int $J$ Syst Bacteriol 47, 127-131.

Cross, T. \& Attwell, R. W. (1974). Recovery of viable thermoactinomycete endospores from deep mud cores. In Spore Research 1973, pp. 11-20. Edited by A. N. Barker, G. W. Gould \& J. Wolf. London: Academic Press.

De Boer, L., Dijkhuizen, L., Grobben, G., Goodfellow, M., Stackebrandt, E., Parlett, J. H., Whitehead, D. \& Witt, D. (1990). Amycolatopsis methanolica sp. nov., a facultatively methylotrophic actinomycete. Int J Syst Bacteriol 40, 194-204.

Di Marco, A. \& Spalla, C. (1957). La produzione di cobalamine da fermentazione con una nuova specie di Nocardia: Nocardia rugosa. G Microbiol 4, 24-30.

Embley, T. M., Smida, J. \& Stackebrandt, E. (1988). The phylogeny of mycolateless wall chemotype IV actinomycetes and description of Pseudonocardiaceae fam. nov. Syst Appl Microbiol 11, 44-52.

Felsenstein, J. (1993). PHYLIP (phylogenetic inference package), version 3.5c. Department of Genetics, University of Washington, Seattle, USA.

Fitch, W. M. \& Margoliash, E. (1967). Construction of phylogenetic trees: a method based on mutation distances as estimated from cytochrome $c$ sequences is of general applicability. Science 155, 279-284.

Goodfellow, M., Lacey, J., Athalye, M., Embley, T. M. \& Bowen, T. (1989). Saccharopolyspora gregorii and Saccharopolyspora hordei: two new actinomycete species from fodder. $J$ Gen Microbiol 135, 2125-2139.

Henssen, A., Kothe, H. W. \& Kroppenstedt, R. M. (1987). Transfer of Pseudonocardia azurea and 'Pseudonocardia fastidiosa' to the genus Amycolatopsis, with emended species description. Int $J$ Syst Bacteriol 37, 292-295.

Jones, J. (1949). Fresh isolates of actinomycetes in which the presence of sporogenous aerial mycelia is a fluctuating characteristic. $J$ Bacteriol 57, 141-145.

Jukes, T. H. \& Cantor, C. R. (1969). Evolution of protein molecules. In Mammalian Protein Metabolism, pp. 21-132. Edited by H. N. Munro. New York: Academic Press.

Kim, D., Chun, J., Sahin, N., Hah, Y. C. \& Goodfellow, M. (1996). Analysis of thermophilic clades within the genus Streptomyces by $16 \mathrm{~S}$ ribosomal DNA sequence comparisons. Int $J$ Syst Bacteriol 46, 581-587.

Kim, S. B., Falconer, C., Williams, E. \& Goodfellow, M. (1998). Streptomyces thermocarboxydovorans sp. nov. and Streptomyces thermocarboxydus sp. nov., two moderately thermophilic carboxydotrophic species isolated from soil. Int J Syst Bacteriol

Kluge, A. G. \& Farris, F. S. (1969). Quantitative phyletics and the evolution of anurans. Syst Zool 18, 1-32.
Korn-Wendisch, F., Kempf, A., Grund, E., Kroppenstedt, R. M. \& Kutzner, H. J. (1989). Transfer of Faenia rectivirgula Kurup and Agre 1983 to the genus Saccharopolyspora Lacey and Goodfellow 1975, elevation of Saccharopolyspora hirsuta subsp. taberi Labeda 1987 to species level, and emended description of the genus Saccharopolyspora. Int J Syst Bacteriol 39, 430-441.

Korn-Wendisch, F., Rainey, F., Kroppenstedt, R. M., Kempf, A., Majazza, A., Kutzner, H. J. \& Stackebrandt, E. (1995). Thermocrispum gen. nov., a new genus of the order Actinomycetales, and description of Thermocrispum municipale sp. nov. and Thermocrispum agreste sp. nov. Int $J$ Syst Bacteriol 45, 67-77.

Labeda, D. P. (1987). Transfer of the type strain of Streptomyces erythraeus (Waksman 1923) Waksman and Henrici 1948 to the genus Saccharopolyspora Lacey and Goodfellow 1975 as Saccharopolyspora erythraea sp. nov. and designation of a neotype strain for Streptomyces erythraeus. Int J Syst Bacteriol

Labeda, D. P. (1995). Amycolatopsis coloradensis sp. nov., the avoparcin (LL-AV290)-producing strain. Int $J$ Syst Bacteriol 45, 124-127.

Labeda, D. P. (1998). Phylogenetic analysis of the genus Saccharothrix and related taxa. In Abstracts of the 98 th General Meeting of the American Society for Microbiology, Atlanta, GA, p. 485. Washington, DC: American Society for Microbiology. Lechevalier, H. A. \& Lechevalier, M. P. (1970). A critical evaluation of the genera of aerobic actinomycetes. In The Actinomycetes, pp. 393-405. Edited by H. Prauser. Jena, Germany: Gustav Fischer Verlag.

Lechevalier, M. P., De Bièvre, C. \& Lechevalier, H. A. (1977). Chemotaxonomy of aerobic actinomycetes: phospholipid composition. Biochem Syst Ecol 5, 249-260.

Lechevalier, M. P., Prauser, H., Labeda, D. P. \& Ruan, J.-S. (1986). Two new genera of nocardioform actinomycetes: Amycolata gen. nov. and Amycolatopsis gen. nov. Int J Syst Bacteriol 36, 29-37.

Mattinson-Rose, A. D. (1986). Classification of amycolate wall chemotype IV actinomycetes. $\mathrm{PhD}$ thesis, University of Newcastle upon Tyne.

Mertz, F. P. \& Yao, R. C. (1993). Amycolatopsis alba sp. nov., isolated from soil. Int J Syst Bacteriol 43, 715-720.

Reichert, K., Lipski, A., Pradella, S., Stackebrandt, E. \& Altendorf, K. (1998). Pseudonocardia asaccharolytica sp. nov. and Pseudonocardia sulfidoxydans sp. nov., two new dimethyl disulfidedegrading actinomycetes and emended description of the genus Pseudonocardia. Int J Syst Bacteriol 48, 441-449.

Saitou, N. \& Nei, M. (1987). The neighbor-joining method: a new method for reconstructing phylogenetic trees. Mol Biol Evol 4, $406-425$.

Shearer, M. C., Colman, P. M., Ferrin, R. M., Nisbet, L. J. \& Nash, C. H., III (1986). New genus of the Actinomycetales: Kibdelosporangium aridum gen. nov., sp. nov. Int $J$ Syst Bacteriol 36, 47-54.

Shirling, E. B. \& Gottlieb, D. (1966). Methods for classification of Streptomyces species. Int $J$ Syst Bacteriol 16, 313-340.

Stackebrandt, E., Rainey, F. A. \& Ward-Rainey, N. L. (1997). Proposal for a new hierarchic classification system, Actinobacteria classis nov. Int $J$ Syst Bacteriol 47, 479-491.

Swofford, D. L. \& Olsen, G. J. (1990). Phylogenetic reconstruction. In Molecular Systematics, pp. 411-501. Edited by D. Hillis \& C. Moritz. Sunderland, MA: Sinauer. 
Warwick, S., Bowen, T., McVeigh, H. \& Embley, T. M. (1994). A phylogenetic analysis of the family Pseudonocardiaceae and the genera Actinokineospora and Saccharothrix with 16S rRNA sequences and a proposal to combine the genera Amycolata and Pseudonocardia in an emended genus Pseudonocardia. Int J Syst Bacteriol 44, 293-299.

Whitehead, D. (1989). Classification, selective isolation and identification of members of the family Pseudonocardiaceae. $\mathrm{PhD}$ thesis, University of Newcastle upon Tyne.

Yassin, A. F., Schaal, K. P., Brzezinka, H., Goodfellow, M. \&
Pulverer, G. (1991). Menaquinone patterns of Amycolatopsis species. Zentbl Bakteriol Series A 274, 465-470.

Yassin, A. F., Haggenei, B., Budzikiewicz, H. \& Schaal, K. P. (1993). Fatty acid and polar lipid composition of the genus Amycolatopsis: application of fast atom bombardment-mass spectrometry to structure analysis of underivatized phospholipids. Int $J$ Syst Bacteriol 43, 414-420.

Yoshida, M., Matsubara, K., Kudo, T. \& Horikoshi, K. (1991). Actinopolyspora mortivallis sp. nov., a moderately halophilic actinomycete. Int $J$ Syst Bacteriol 41, 15-20. 